\title{
Comparative Study on the Efficiency of Bangladeshi Conventional and Islamic Life Insurance Industry: A Non- Parametric Approach
}

\author{
Md. Azizur Rahman
}

Faculty in Finance, Department of Business Administration, International Islamic University Chittagong, Bangladesh

\begin{abstract}
This study endeavor is to examine the efficiency in the both life insurance and life Takaful industry of Bangladesh. The study used Data Envelopment Analysis (DEA) to explore the contributions of technical and efficiency changes to the growth of productivity in the life insurance industries of Bangladesh by using descriptive statistics such as mean, median, standard deviation, minimum $\mathcal{E}$ maximum and efficiency concerning the generalized output-oriented Malmquist index for the years 2009-2011. The output-input data consists of a panel of 13 Life Insurance and Takaful Life companies (10 life insurance and 03 Takaful life) in Bangladesh. This study utilizes two inputs and two outputs, namely, commission and management as well as premium and net investment income, respectively. In the DEA technique, efficiency is measured by the Malmquist index. The Malmquist efficiency measures have two components: the efficiency change and technical change index. Efficiency change is again combined by pure efficiency and scale efficiency. It is found that, on geometric mean, the TFP of the Conventional life industry is better than Takaful life mainly due to both efficiency and technical changes where the main source of the efficiency change is scale efficiency rather than pure efficiency. Finding of this study indicates that Conventional and Takaful life industry of Bangladesh, the smaller the size of the companies, the higher the probability for the companies to be more efficient in utilizing their inputs to generate more outputs. This work will beneficial for researchers as well as practitioners to better understand the Bangladeshi life insurance industry.
\end{abstract}

Keywords: Data Envelopment Analysis (DEA); Takaful; Malmquist Index; Efficiency; Technical Efficiency; Scale Efficiency; Pure Efficiency

JEL Classification Codes: C14, C67, D57, G22

\section{INTRODUCTION}

$\mathrm{U}$ ltimate intention is to find the efficiency of life insurances industry in Bangladesh both the conventional life and Takaful life insurances and this study try develop the whole work also to seek the potentiality of this sector. The primary function of insurance is to act as a risk transfer mechanism to provide peace of mind and protect against the future losses (Sabbir, 2002). In addition to this, there have been available studies both locally and internationally in other financial fields especially depository institutions only a handful has been concerned with the insurance industry in Bangladesh on the performance. This work tries to find the lacking of Life Insurances Company. That is why it feels interest to study in this industry. As maximum percentages of total population are Muslim and where Islamic finance and Takaful insurance products are growing worldwide in a way that is encouraging their adoption by Islamic as well as non-Islamic countries to support economic growth. Recently, Islamic finance has become one of the most rapidly growing segments of the global financial system. The reason it works here in this industry why people are feeling less keen about life insurance? This is because they freely use general insurance in their export and import business. What is the hindrance behind this? These are the most considerable research questions of this study.

The developing country like Bangladesh has very much potentiality for this sector in near future. Efficiency comparisons at the international level have received significant attention in the insurance literature. This result indicates that insurance industries have a great potential to further increase their TFP through improvements in both efficiency and technical component such as enhancing the use of information and communication technology in order to provide good services to customers (Jesmin et al. 2013) .This study expect certainly contribute to their economy. In the present globe, Islamic banking industry has assets worth over $\$ 900$ billion, and Islamic finance has spread to 75 countries from East to West, extending from Muslim to non-Muslim countries.

The introduction of an Islamic model of insurance has boosted the Islamic world economy, according to many reports. Insurance has become the biggest industry in 
Saudi Arabia's economy having overtaken the banking, real estate and manufacturing sectors. Bangladesh is trying to do well in this sector. It will find how she may be able to improve in insurance, what are steps taken by govt. and organization etc. This study works attempt to seek these questions in this research. If it abide by that the people of this country are fully Islamic minded then why they don't use Takaful life insurance? The world's first Takaful insurance company was established in Sudan in 1979, and since then Takaful insurance companies have spread around the world. On the contrary, the first Takaful insurance company was established in Bangladesh in January, 2000 and then no other Takaful insurance company has been established after 2007. Why Takaful life insurance or even conventional life insurance doesn't grow up at the desire level though this is an enormous demanded industry in Bangladesh? Is the life insurance companies can't satisfy their expectation or the life insurance industries are inefficient to ensure them? Because of this, the researcher wants to examine main reasons behind this stagnancy by measuring efficiency. The diversification of insurance models and types has encouraged customers to choose between them according to their needs, perceptions and beliefs. Identification of customers' reasons for acquiring particular forms of insurance helps to highlight the weaknesses and strengths of the different forms.

There are vast probabilities of success in life insurance industry in this country. Hence, this study makes to evaluate the efficiency. The efficiency of financial institutions has been widely and extensively studied in the last few decades. For financial institutions, efficiency implies improved profitability, greater amount of funds channeled in, better prices and services quality for consumers and greater safety in terms of improved capital buffer in absorbing risk (Berger et al., 1993). As there have sound possibilities of improvement, so why existing life insurance companies cannot reach their ultimate goal. To find these matters this works have sought. This study measure the actual productivity of life insurances industries. Furthermore, it also tries to search the relationship with industries. This work will help to understand and reorganize about life insurances companies in Bangladesh. People will be keen to use life insurance very soon. In various researches seen that financially developed countries accustom with life insurance in their practical life like study of their children's health insurance is mandatory and so on. However, interestingly here in Bangladesh is not practiced. This study is also tried to identify the relationship with financial literacy. Government may help them to improve their performance. By encouraging people huge investment can be possible in this sector which will certainly contribute in total economy. The narrow objectives of this study are to measure the efficiency of Islamic and conventional life insurance of this country. Is there any wanting in insurance company themselves? Which insurance sector is doing well? How they are correlated and difference in their actions. By this work try to define that's problem and way to get the elucidations.

There are wide fields of research in financial industries. Study may be taken different industries but there are sound works in this sector than other industries. As Bangladesh is least developing country where there lot of potentiality especially in life insurance. Due to require steps both govt. and non govt. organizations she cannot show her productivity. That is why this study focuses on life insurances. It may assist the concerned department to rethink about life insurance. Emphasis is given to bring the actual potentiality of this field. The study of efficiency of life insurance companies is important for the Bangladesh dual financial system where the Takaful operators are operating alongside their conventional counterparts. Furthermore, the Bangladeshi financial system has undergone major structural changes in the era of globalization with various liberalization measures being introduced during the last decade. These factors are expected to have an impact on the efficiency of the life and non-life Takaful operators. Therefore, this study focuses on two aspects of Takaful industry in Bangladesh. Firstly, it aims to extend the established an individual sector by investigating the efficiency of the whole Takaful operators for the period 2009-2011. Secondly, it seeks to compare the performance of conventional life and Takaful life operators in Bangladesh. For the Takaful operators, the information obtained on the evaluation of the institutions' performance may be used to improve the overall efficiency of their operations and in turn, may contribute towards achieving its competitive edge. In this context, the objective of this study is to analyze the sources of efficiency and technical changes in both the life and non-life Takaful companies in Bangladesh. By using the non-parametric approach of Data Envelopment Analysis (DEA) together with Malmquist Index, this study isolate the contributions of technical change, efficiency change, the pure and scale changes to total factor productivity growth of different life and non-life Takaful operators in Bangladesh.

This study is organized by the combination of multisections such as Section-2 reviews the relevant literature; Section-3 discusses the methodology of DEA and Malmquist Index; Section-4 presents the results and analysis, and finally Section-5 presents conclusion with some recommendations.

\section{Literature Review}

There are sufficient studies on measuring performances of financial efficiency in various sectors but few in insurance field especially when the country faces several challenges political unrest, rate of inflation is in dual digit, risen competition, problem in solvency and devaluation of taka (local currency). Like other developed countries Bangladesh is also trying to create 
more efficient market in insurance sector. Though there are some hindrances like unconsciousness about insurance, poverty and disinterest in money etc. but the neighboring country like India is far better position in savings tendency. Nevertheless, interestingly it is seen that people are getting conscious about their future.

In spite of these challenges there still remain incredible opportunities for increasing market penetration in the core markets of leading Muslim countries in Asia, Africa and some non Muslim countries with significant Muslim populations. ITS 'New Frontiers' will investigate the obstacles faced by the industry and seek to provide constructive solutions to nurture the continued development of the global industry. Though this is not an Islamic state but maximum or near about ninety percent people is Muslim. That is why Takaful concept is developing here in Bangladesh though there is an established conventional life insurance industry. The question of the efficiency of the firms in insurance industry is very important in order to determine how the insurance industry will respond to various challenges and which firms are likely to survive (Berger et. al, 1993). There are some previous studies on the efficiency of insurance industry using DEA provided evidence to understand the performance of the insurance sector in certain countries, e.g. those studies which analyze insurance in national markets such as the case in the United States done by Berger et al. (1997), Cummins et al. (1999), Meador et al. (2000), Gardner and Grace (2002), and Cummins and Weiss (2002), Cummins et al. (2010) and the insurance industries in other countries like in Japan, Italy, United Kingdom, Australia, Spain, and Germany have been studied by Fukuyama (1997), Cummins et al. (1996), Diacon (2001), Worthington and Hurley (2002), Cummins and Rubio-Misas (2001), and Mahlberg and Url (2010) respectively. Besides that, there are also studies that conduct analyses of the insurance industry in multi-markets such as Rees and Kessner (2000) and Diacon et al. (2002) where they have conducted studies by internationally comparing the efficiency of insurance companies in Europe.

A study undertaken by Cummins et al. (1996) measured technical efficiency and productivity growth in the Italian insurance market by estimating production frontiers based on a sample of 94 Italian insurers for the period 1985-1993. In this study, they found that technical efficiency in the Italian insurance industry ranged from 70 to 78 percent and measured total factor productivity gains of about 3.4 percent during the sample period. There was almost no efficiency change over the sample period, i.e. on average, Italian insurers operated at about the same distance from the production frontier throughout the sample period. However, productivity declined significantly over the sample period, with a cumulative decline of about 25 percent. The decline was attributable almost exclusively to technological regress, implying that the Italian insurers needed more inputs to produce their outputs at the end of the sample period than at the beginning.

Comparing the results of the three countries' insurance industries with their United States counterparts, in terms of total factor productivity growth which is measured by the Malmquist index, the Japanese life insurers (Fukuyama, 1997) and the Italian life and propertyliability insurers (Cummins et al., 1996) indicate efficiency gains that are considerably higher than in the U.S. In the case of the Spanish insurance industry, Cummins and Rubio-Misas (2001) found that cost efficiencies for Spanish insurers are low compared to the U.S insurers. Besides studies on a country-level basis, there are studies on the international comparison on the efficiency of insurance companies such as in Europe. Rees and Kessner (2000) found that the average efficiency level of the German firms was about 48 percent and the average efficiency level of the British firms was markedly higher, with a mean of around 57 percent and median of 52 percent. On the other hand, Diacon et al. (2002) found that, when a comparison was made between insurance companies in the U.K., Spain, Sweden and Denmark, U.K. insurers appear to have particularly low levels of scale and mix efficiencies. The measurement of insurance efficiency is mostly focused on the efficient frontier approach. This has been used widely to assess the efficiency levels as both approaches allow the use of multiple inputs and outputs from a sample of institutions to develop an efficiency frontier and evaluate the efficiency of a decision-making unit (DMU) relative to other DMUs in the sample. According to a survey conducted by Berger and Humphrey (1997) on 130 past studies that apply frontier efficiency analysis to financial institutions in 21 countries, there are various methods used to measure efficiency. These methods are divided into two approaches namely parametric and non-parametric. The most commonly used parametric approaches are the Stochastic Frontier Approach (composed error), Distribution Free Approach (different composed error) and the Thick Frontier Approach. For non-parametric approaches, the most commonly used are the Data Envelopment Analysis and the Free Disposable Hull [Cummins et al. (1999); Cummins and Zi (1998)].

In addition, considering the Malaysian dual financial system environment where the Takaful operators are operating in parallel with their conventional counterparts, another study was undertaken by $\mathrm{Md}$. Saad et al. (2007) found that on average, the total factor productivity growth of the insurance industry in Malaysia is mainly due to technical change while efficiency change contributed a negative change. While Takaful presents a below average in total factor productivity but slightly above average for technical change as well as an equal to industry average in scale efficiency. However, this result is still inconclusive on 
the Takaful industry as a whole since only one Takaful company is included in the study. Fukuyama (1997) investigated productive efficiency and productivity changes of Japanese life insurance companies by focusing primarily on the ownership structures (mutual and stock) and economic conditions (expansion and recession) where he found that productive efficiency and productivity performances differ from time to time across the two ownership types under different economic conditions. Fukuyama (1997) found that stock and mutual life insurers in Japan have approximately equal technical efficiency scores. For the sample period 1989-1992, Fukuyama (1997) found the average technical efficiency in the Japanese life insurance industry to be about 0.91 (Cummins et al., 1996) and a total factor productivity gains of about 19 percent.

The Takaful industry is facing strategic challenges as the market establishes itself. Significant investments are required to establish the Shari'ah board, develop technical expertise on Shari'ah compliance, train staff, create brand awareness among customers, as well as implementing the appropriate technology. To ensure the success and sustainability of the Takaful and re-Takaful industry, the companies will need to work with their respective national regulator to address impediments facing the industry. Despite all the challenges, Takaful is a viable alternative to conventional insurance and is expected record gross Takaful contribution of $\$ 17.2 \mathrm{bn}$ by end of 2012. (Source WTR, 2012)

\section{Data Sources and Methodology}

This study intends to measure the comparative efficiency between conventional life and Takaful life operators of the insurance industry of Bangladesh. There are 02 public insurance companies these are Jibon Bima Corporation and Sadaron Bima Corporation both are established in1973.There were no insurance company except these two till 1985. There are now 43 privately owned general companies and 17 life insurers in Bangladesh. Met Life American Life Insurance Company was the first private company in Bangladesh established in 1974. There are 09 Takaful operators are operated in Bangladesh, out of which the data of three foreign companies namely First Takaful Insurance Company, Noor Takaful insurance company limited and National Takaful Insurance Company operators were not accessible. The data of remaining 17 companies 03 Takaful Life Operators and 10 Life Insurer has been considered for efficiency analysis in this study. Two inputs and outputs are used in this study. The inputs are commission and management expenses and the outputs are premium and net investment income. These inputs and outputs are used to observe the efficiency of three (03) life Takaful operators in Bangladesh, namely Fareast Islami Life Insurance Company, Padma Life Islami Insurance Limited and Prime Islami Life Insurance
Limited and ten (10) conventional life Insurance Operators in Bangladesh, namely: National Life Insurance Limited, Delta Life Insurance Limited, Baira Life Insurance Limited, Meghna Life Insurance Limited, Popular Life Insurance Limited, Pragoti Life Insurance Limited, Progressive Life Insurance Limited, Rupali Life Insurance Limited, Sandhani Life Insurance Limited, Sunlife Insurance Limited. Inputs and outputs data are collected from period of 2009 to 2011. The data are gathered from the respective Takaful annual reports, websites and chief finance officer (for Islami Commercial Insurance Company and Delta life Insurance Company because of unavailable audited annual report).

To examine the contributions of technical and efficiency change to the growth of productivity in the both life and non-life Takaful industries the generalized outputoriented Malmquist index, developed by Fare et al. (1989) is adopted in this study. The Malmquist indexes are constructed using the Data Envelopment Approach (DEA) and estimated using Coelli's (1996) DEAP version 2.1. Malmquist index was chosen as there are a number of desirable features for this particular study. The DEA does not only require input prices or output prices in their construction, which make the method particularly useful in situations in which prices are not available publicly or non-existent, but it also does not require a behavioral assumption such as cost minimization or profit maximization in the case where the producers' objectives differ, unknown or achieved. This is first demonstrated by Fare et al. (1989) using the geometric mean formulation of the Malmquist index. Following this, Forsund (1991) derived the decomposition of the simple version of the Malmquist productivity index into technical change and efficiency change. Following Fare et al. (1989), the Malmquist index of total factor productivity growth is written as follows:

$$
\begin{gathered}
M_{0}\left(x^{t}, y^{t}, x^{t+1}, y^{t+1}\right)=\frac{D_{0}^{t+1}\left(x^{t+1}, y^{t+1}\right)}{D_{0}^{t}\left(x^{t}, y^{t}\right)} \\
\times \sqrt{\left[\left(\frac{D_{0}^{t}\left(x^{t+1}, y^{t+1}\right)}{D_{0}^{t+1}\left(x^{t+1}, y^{t+1}\right)}\right)\left(\frac{D_{0}^{t}\left(x^{t}, y^{t}\right)}{D_{0}^{t+1}\left(x^{t}, y^{t}\right)}\right)\right]}
\end{gathered}
$$

Where, $D_{0}^{t}\left(x^{t+1}, y^{t+1}\right)$, denoted the distance from the period $t+1$ observation to the period $t$ technology. The first part of the right hand side of equation (1) measures the change in firm's relative efficiency (i.e., distance between the observed productions from maximum potential production) between year $t$ and $t+1$. On the other hand, second parts of this equation within the brackets (geometric mean of the two ratios) shows the firms' relative change in technology (i.e., movements of the frontier function itself) between the two periods evaluated at $x^{t}$ and $x^{t+1}$. Basically, the change in relative efficiency measures how well the production process 
converts inputs into outputs (catching up to the frontier) and the later reflects enhancement in technology. According to Fare et al. (1994a), improvements in productivity yield Malmquist index values greater than unity. Deterioration in performance over time is associated with a Malmquist index less than unity. The same interpretation applies to the values taken by the components of the overall TFP index.

The positive change in the efficiency component yielded index values greater than one and is considered to be evidence of catching up (to the frontier). Values of the technical change component greater than one are considered to be evidence of technological progress. Following Fare et al. (1994), this study uses an enhanced decomposition of the Malmquist index by decomposing the efficiency change component calculated relative to the constant returns to scale technology into a pure efficiency component (calculated relative to the VRS technology) and a scale efficiency change component which captures changes in the deviation between the VRS and CRS technology. The subset of pure efficiency change measures the relative ability of operators to converts inputs into outputs while scale efficiency measures to what extent the operators can take advantage of returns to scale by altering its size toward optimal scale.

\section{FINDINGS AND ITS ANALYSIS}

\subsection{Measures of some Descriptive Statistics}

This works aspires to evaluate some descriptive statistics such as mean, median, Standard Deviation, minimum and maximum before run data envelopment analysis. Table- 1 reveals the descriptive statistics of the outputs and inputs of all the Takaful Life Insurance and Conventional Life Insurance companies during the study period. The overall success rate of conventional life insurance are good than Takaful Life insurance companies .By investing more conventional firm makes higher output where Takaful shows less input and results is a low amount of output. Though some conventional life Insurance like Sun life Insurance Company makes only 586.27 and 15.73 million BDT premium and investment income on the other hand Takaful shows 1111.90 and 116.07 million BDT respectively. Hence, the performance of Takaful companies is indicating better results.

In terms efficiency conventional life insurance are in much position compare to Takaful life insurance companies due to managing the money more perfectly. So the ultimate output of conventional life insurance are 60488 million BDT and 9535 million BDT as premium and investment income respectively where Takaful life insurance companies shows only 6908 million BDT and 1131.33 million BDT respectively which means near about $9 \%$ higher than Takaful life insurance companies.

Table 1: Descriptive Statistics, 2009-2011
\begin{tabular}{|c|c|c|c|c|c|}
\hline \multirow{4}{*}{$\begin{array}{c}\text { Types Of } \\
\text { Insurance }\end{array}$} & Statistics & \multicolumn{2}{|c|}{$\begin{array}{c}\text { Inputs } \\
\text { (In million BDT) }\end{array}$} & \multicolumn{2}{c|}{$\begin{array}{c}\text { Outputs } \\
\text { (In million BDT) }\end{array}$} \\
\cline { 3 - 6 } & $\begin{array}{c}\text { Commi } \\
\text { ssion }\end{array}$ & $\begin{array}{c}\text { Manage } \\
\text { ment } \\
\text { Expenses }\end{array}$ & Premium & $\begin{array}{c}\text { Invest } \\
\text { ment } \\
\text { Income }\end{array}$ \\
\hline \multirow{4}{*}{$\begin{array}{c}\text { Takaful } \\
\text { Life }\end{array}$} & Mean & 931.44 & 458.95 & 3298.26 & 490.50 \\
\cline { 2 - 6 } & Median & 538.45 & 368.80 & 1791.83 & 356.07 \\
\cline { 2 - 6 } & SD & 744.94 & 227.06 & 2476.69 & 316.08 \\
\cline { 2 - 6 } & Minimum & 325.75 & 240.30 & 1111.90 & 116.07 \\
\cline { 2 - 6 } & Maximum & 2213.71 & 849.04 & 6908.76 & 1131.33 \\
\hline \hline \multirow{4}{*}{$\begin{array}{c}\text { Life } \\
\text { Insurance }\end{array}$} & Mean & 3266.99 & 3030.37 & 14031.2 & 2113.87 \\
\cline { 2 - 6 } & Median & 884.87 & 842.59 & 5110.57 & 1168.96 \\
\cline { 2 - 6 } & SD & 4343.19 & 3672.68 & 17376.51 & 2743.25 \\
\cline { 2 - 6 } & Minimum & 197.04 & 85.83 & 586.27 & 15.73 \\
\cline { 2 - 6 } & Maximum & 14206 & 13218 & 60488 & 9353 \\
\hline
\end{tabular}

Source: Annual Reports of respective Companies

\subsection{Production Frontier and Efficiency}

In this section, the study is to outline a number of commonly used efficiency measures and to discuss how they calculated relative to an efficient technology, which is generally represented by some form of frontier function. Tables 2 and 3, reports efficiency change for both life insurance and Takaful life insurance companies from 2009-2011 under constant returns to scale (CRS) and variable returns to scale (VRS) respectively, since the basic component of the Malmquist productivity index is related to measures of efficiency. For the values of unity, the firm is implied to be on the industry frontier in the related year, while the values that are less than unity imply that the firm is below the frontier or technically inefficient. Thus, the lower the values from unity, the firm is said to be more inefficient compared to the values closer to one.

According to portrayed result in tables 2 and 3, all the Takaful companies and life Insurance are consistently efficient during the study periods 2009 to 2011 in two types of Insurance operators, under constant returns to scale (CRS) except Padma Islami Life insurance Limited in Takaful life where Baira Life Insurance and Pragoti Life Insurance Company in terms of Conventional life insurance. Meanwhile, the efficiency (CRS) of Padma Islami life insurance Limited increased to standard within the study periods but the efficiency (CRS) position is going to little bit risen in terms of Conventional Insurance Company.

Thus the overall Takaful life insurance companies are more constant to their performance, but the study shows conventional life insurance companies are not sound enough as Takaful life insurance with less average consistency. In contrary, all the Takaful operators are consistently efficient under Variable Return to Scale (VRS) except Padma Islami Life Insurance Limited in 2009 and Baira Life Insurance Limited and Pragoti Life Insurance Limited in 2009. 
Asian Business Review, Volume 3, Number 2/2013 (Issue 5)

ISSN 2304-2613 (Print); ISSN 2305-8730 (Online)

Table 2: Efficiency of the Insurance Firms, 2009-2011 (Constant Returns to Scale)

\begin{tabular}{|c|l|c|c|c|}
\hline $\begin{array}{c}\text { Types of } \\
\text { Insurance }\end{array}$ & Name of the Insurance Company & $\mathbf{2 0 0 9}$ & $\mathbf{2 0 1 0}$ & $\mathbf{2 0 1 1}$ \\
\hline \multirow{4}{*}{$\begin{array}{c}\text { Takaful } \\
\text { Life }\end{array}$} & Fareast Islami Life Insurance Co. Ltd. & 1.000 & 1.000 & 1.000 \\
\cline { 2 - 5 } & Padma Islami life insurance Ltd. & 0.746 & 0.756 & 0.991 \\
\cline { 2 - 5 } & Prime Islami life Insurance Ltd. & 1.000 & 1.000 & 1.000 \\
\hline \multirow{4}{*}{ Mean } & $\mathbf{0 . 9 1 5}$ & $\mathbf{0 . 9 1 9}$ & $\mathbf{0 . 9 9 6}$ \\
\hline \multirow{4}{*}{\begin{tabular}{l} 
Life \\
\cline { 2 - 5 }
\end{tabular}} & National Life Insurance Co. Ltd. & 1.000 & 1.000 & 1.000 \\
\cline { 2 - 5 } & Delta Life Insurance Bangladesh Ltd. & 1.000 & 1.000 & 1.000 \\
\cline { 2 - 5 } & Baira Life Insurance Ltd. & 0.175 & 0.258 & 0.249 \\
\cline { 2 - 5 } & Meghna Life Insurance Company Ltd. & 0.644 & 0.797 & 0.781 \\
\cline { 2 - 5 } & Popular Life Insurance Company Ltd. & 1.000 & 0.800 & 0.722 \\
\cline { 2 - 5 } & Pragoti Life Insurance Company Ltd. & 0.285 & 0.292 & 0.388 \\
\cline { 2 - 5 } & Progressive Life Insurance Co. Ltd. & 1.000 & 1.000 & 1.000 \\
\cline { 2 - 5 } & Rupali Life Insurance Company Ltd. & 0.795 & 0.961 & 0.906 \\
\cline { 2 - 5 } & Sandhani Life insurance Co. Ltd. & 0.936 & 0.824 & 0.724 \\
\cline { 2 - 5 } & Sunlife Insurance Company Ltd. & 1.000 & 0.98 & 0.933 \\
\cline { 2 - 5 } & Mean & $\mathbf{0 . 7 8 3}$ & $\mathbf{0 . 7 9 1}$ & $\mathbf{0 . 7 7}$ \\
\hline
\end{tabular}

Tables 2 and 3 depict the percentage of the realized output level compared to the maximum potential output level at the given input mix. In 2009, Baira Life Insurance Company produced 17.5 percent and Pragoti Life Insurance 28.5 percent of their potential output level and Padma Islami Life Insurance Limited produced 74.6 percent of its potential output under CRS. On the other hand, under VRS in the same year, the Padma Islami insurance Limited produced the potential output 84.4 percent whereas Baira Life Insurance Company produced at their maximum potential output, which was at 100 percent where Pragoti Life Insurance made 62.9 percent. In 2010 Baira Life Insurance Company produced 25.8 percent of its potential output level and further extensive decrease in 2011, while Pragoti Life Insurance made 29.2 percent of its potential output level and later increased and Padma Islami Insurance Limited produced 75.6 percent of its potential output under CRS. Under the VRS, Baira Life Insurance Bangladesh Limited produced 29.6 percent of its potential output level but fall by 2.2 percent in later year which was minimum potential output of used year in insurance operators. Under VRS in the same year, the Padma Islami Life insurance Limited produced the potential output as same as percent whereas Baira Life Insurance Company produced at their maximum potential output, same as 2009. As indicated by the weighted geometric mean in Tables 2 and 3, the average efficiency for the Takaful life insurances industries increases and decreased for conventional life insurances industries for the period 2009 to 2011 under CRS. Meanwhile, under VRS, the average efficiency for Takaful life insurances industries has seems to be value of unity reached at maximum potential output, which was at $100 \%$ percent in the year 2010 and 2011 and shows slightly lower in 2009. The mean efficiency of conventional life insurances was good in 2009 but later less than Takaful life insurances companies due to Baira Life Insurance and Pragoti Life Insurance in 2010 and 2011. Except this twos overall performances of both life insurances industries are at satisfactory level On average, efficiency performance of the Takaful life insurances industry is relatively higher based on VRS than CRS.

Table 3: Efficiency of the Insurance Firms, 2009-2011 (Variable Returns to Scale)

\begin{tabular}{|c|c|c|c|c|}
\hline & Name of the Insurance Company & 2009 & 2010 & 2011 \\
\hline \multirow{4}{*}{$\begin{array}{l}\text { Takaful } \\
\text { Life }\end{array}$} & Fareast Islami Life Ins & 1.000 & 1.000 & 1.000 \\
\hline & Padma Islami life insurance Limited & 0.844 & 1.000 & \\
\hline & Prime Islami life Insurance Limited & 1.000 & 1.000 & 1.000 \\
\hline & \begin{tabular}{|c|} 
Mean \\
\end{tabular} & 0.948 & 1.000 & 1.000 \\
\hline \multirow{11}{*}{$\begin{array}{c}\text { Life } \\
\text { Insurance }\end{array}$} & National Life Insurance Company Ltd. & 1.000 & 1.000 & 1.000 \\
\hline & Delta Life Insurance Bangladesh Ltd. & 1.000 & 1.000 & 1.000 \\
\hline & Baira Life Insurance Ltd. & 1.000 & 0.296 & 0.274 \\
\hline & Meghna Life Insurance Company Ltd. & 1.000 & 1.000 & 1.000 \\
\hline & Popular Life Insurance Company Ltd. & 1.000 & 1.000 & 1.000 \\
\hline & Pragoti Life Insurance Company Ltd. & 0.629 & 0.292 & 0.400 \\
\hline & Progressive Life Insurance Co Ltd. & 1.000 & 1.000 & 1.000 \\
\hline & Rupali Life Insurance Company Ltd. & 1.000 & 1.000 & 0.922 \\
\hline & Sandhani Life insurance Co Ltd. & 1.000 & 1.000 & 1.000 \\
\hline & Sunlife Insurance Company Ltd. & 1.000 & 1.000 & 1.000 \\
\hline & Mean & 0.963 & 0.859 & 0.860 \\
\hline
\end{tabular}

\subsection{Productivity Performance of the Life Insurances Company}

As Malmquist Total Factor Productivity (TFP) index to measure productivity change and to decompose these productivity change into technical change and technical efficiency change. Table- 4 and table- 5 report the performance of the firms from 2009 to 2011 in terms of TFP change and its two subcomponents which are technical change and efficiency change respectively. Note that a value of the Malmquist TFP productivity index and its components of greater than one imply improvements of productivity in the relevant aspects, while values less than one indicate a decrease or deterioration in productivity. Subtracting 1 from the number reported in the table gives an average increase or decrease per annum for the relevant time period and relevant performance measure. These measures also capture the performance relative to the best practice in the relevant performance or relative to the best practice in the sample.

Table 4: Insurance Firms Relative Malmquist TFP Change between Time Period $t$ and $t+1,2009-2011$

\begin{tabular}{|c|l|c|c|c|}
\hline \multirow{2}{*}{ Types } & Name of the Insurance Company & $\begin{array}{c}\mathbf{2 0 0 9 -} \\
\mathbf{2 0 1 0}\end{array}$ & $\begin{array}{c}\mathbf{2 0 1 0} \\
\mathbf{2 0 1 1}\end{array}$ & Mean \\
\hline \multirow{4}{*}{$\begin{array}{c}\text { Takaful } \\
\text { Life }\end{array}$} & Fareast Islami Life Insurance Co Ltd. & 0.868 & 0.837 & 0.853 \\
\cline { 2 - 5 } & Padma Islami life insurance Limited & 0.982 & 1.259 & 1.121 \\
\cline { 2 - 5 } & Prime Islami life Insurance Ltd. & 0.908 & 0.957 & 0.9330 \\
\cline { 2 - 5 } & Mean & $\mathbf{0 . 9 1 9}$ & $\mathbf{1 . 0 1 8}$ & $\mathbf{0 . 9 6 9 0}$ \\
\hline \multirow{3}{*}{$\begin{array}{c}\text { Life } \\
\text { Insurance }\end{array}$} & National Life Insurance Co. Ltd. & 0.995 & 0.984 & 0.9895 \\
\cline { 2 - 5 } & Delta Life Insurance Bangladesh Ltd. & 1.182 & 0.799 & 0.9905 \\
\cline { 2 - 6 } & Baira Life Insurance Ltd. & 0.996 & 1.019 & 1.0075 \\
\cline { 2 - 6 } & Meghna Life Insurance Co. Ltd. & 1.007 & 1.018 & 1.0125 \\
\hline
\end{tabular}




\begin{tabular}{|l|l|l|l|l|}
\hline \hline \multirow{7}{*}{} & Popular Life Insurance Co. Ltd. & 0.848 & 0.950 & 0.8990 \\
\cline { 2 - 5 } & Pragoti Life Insurance Co. Ltd. & 0.773 & 1.400 & 1.0865 \\
\cline { 2 - 5 } & Progressive Life Insurance Co. Ltd. & 1.109 & 1.090 & 1.0995 \\
\cline { 2 - 6 } Rupali Life Insurance Co. Ltd. & 1.165 & 0.872 & 1.0185 \\
\cline { 2 - 6 } Sandhani Life insurance Co. Ltd. & 0.875 & 0.841 & 0.8580 \\
\cline { 2 - 6 } Sunlife Insurance Co. Ltd. & 0.922 & 0.881 & 0.9015 \\
\cline { 2 - 5 } & $\mathbf{0 . 9 7 9}$ & $\mathbf{0 . 9 7 0}$ & $\mathbf{0 . 9 7 4 5}$ \\
\hline
\end{tabular}

Table 4 portrays considered changes in the Malmquistbased Total Factor Productivity index. As shown in the results, Progressive Life Insurance Bangladesh Limited and Rupali Life Insurance have positive productivity changes during the adjacent years of 2009-2010, 2010-2011. And Meghna Life Insurance does well from 2009 to 2011. Moreover, Padma IslamiI Insurance Limited recorded slight corrosion in TFP for the year 2009-2010 where in the next year recorded noticeable advance in TFP at 20102011. Though both life insurance operators have positive glowing change for the adjacent years 2009-2010, 20102011 but conventional life insurance makes slightly sound. On the other hand, Fareast Islami Life Insurance Limited and Sandhani Life Insurance Limited have little positive productivity changes for the adjacent years of 2009-2010, but they ended descent in efficiency in 2010-2011. Meanwhile, Prime Islami Insurance Limited has faced affirmative productivity changes during the adjacent years of 2009-2010 and 2010-2011. In addition, Padma Life Insurance Limited has taken up the first rank with 27.7 percent average TFP annual growth rate followed by Prime Islami Life Insurance Limited with an annual rate of 4.9 percent and Fareast Islami Life Commercial Insurance Company with $3.1 \%$ deterioration in the period of 20102011. At the same year in case of conventional life insurance, Pragoti Life insurance Limited occupied first rank with an annual rate of 62.7 percent while Rupali Life Insurance vivid falls by 29.3 percent. In addition, in terms of Takaful life insurances TFP change, on average, only showed significant deterioration of growths in the periods of 2009-2010, with 08.10 percent. However, it improved in 2010-2011, which is 01.8 percent. On the other hand, in terms of conventional life insurance, the TFP change, on average, only showed significant improvement in growths for the periods of 2009-2010, but it deterioration in 20102011, which is 0.9 percent.

The Malmquist TFP index is further decomposed into its two components, technical change and efficiency change. The results of technical change and efficiency change are showed in Tables 5 and 6 . Table 5 portrays the index values of technical advancement or retreat as measured by average shifts in the best-practice frontier from period $t$ to $t+1$. According to the results, both types of Takaful operators experienced technical progress and retreat. However, all conventional life insurance have experienced technical progress for the periods of 2009 to 2011 except Rupali Life Insurance Limited and Sunlife Life Insurance Limited companies. In contrast, all three Takaful life insurance are experienced technical retreat for the periods of 2009 to 2011.
During the study period Takaful Life Insurance have positive productivity changes for the years of 2009-2010, but they faced a notable improvement in productivity in 20102011. On the other hand, Delta Life Insurance Limited has been achieved the maximum change in technical progress (18.2 percent) in the period 2009-2010 and maximum retreat in 2010-2011, while Popular Life Insurance Limited achieved the highest technical growth between the period 2010-2011 with 6.7 percent.

During the study period, all conventional life insurance have achieved positive average technical progress but on the contrary all three Takaful life insurance have experienced average technical retreats. By considering the mean, Delta Life Insurance Bangladesh Limited occupies first rank with 99.5\%, followed by Popular Life Insurance Company with $1.85 \%$. In contrast, Fareast Islami Life Insurance Company was found as the most technical regressive firm (14.7 percent).

Table 5: Insurance Operators Relative Technical Change, 2009-2011

\begin{tabular}{|c|l|c|c|c|}
\hline Types & Name of the Insurance Company & $\begin{array}{c}\mathbf{2 0 0 9 -} \\
\mathbf{2 0 1 0}\end{array}$ & $\begin{array}{c}\mathbf{2 0 1 0} \\
\mathbf{2 0 1 1}\end{array}$ & Mean \\
\hline \multirow{4}{*}{$\begin{array}{c}\text { Takaful } \\
\text { Life }\end{array}$} & Fareast Islami Life Insurance Co Ltd & 0.868 & 0.837 & 0.853 \\
\cline { 2 - 5 } & Padma Islami life insurance Ltd. & 0.969 & 0.951 & 0.960 \\
\cline { 2 - 5 } & Prime Islami life Insurance Ltd. & 0.908 & 0.957 & 0.933 \\
\cline { 2 - 5 } & Mean & $\mathbf{0 . 9 1 5}$ & $\mathbf{0 . 9 1 5}$ & $\mathbf{0 . 9 1 5}$ \\
\hline \multirow{5}{*}{$\begin{array}{c}\text { Life } \\
\text { Insurance }\end{array}$} & National Life Insurance Co. Ltd. & 0.995 & 0.984 & 0.9895 \\
\cline { 2 - 5 } & Delta Life Insurance Bangladesh Ltd. & 1.182 & 0.799 & 0.9905 \\
\cline { 2 - 5 } & Baira Life Insurance Ltd. & 0.998 & 1.053 & 1.0255 \\
\cline { 2 - 5 } & Meghna Life Insurance Co. Ltd. & 1.028 & 1.036 & 1.032 \\
\cline { 2 - 5 } & Popular Life Insurance Co. Ltd. & 0.985 & 1.052 & 1.0185 \\
\cline { 2 - 5 } & Pragoti Life Insurance Co. Ltd. & 1.007 & 1.054 & 1.0305 \\
\cline { 2 - 5 } & Progressive Life Insurance Co Ltd. & 1.109 & 1.090 & 1.0995 \\
\cline { 2 - 5 } & Rupali Life Insurance Co. Ltd. & 0.964 & 0.926 & 0.9450 \\
\cline { 2 - 5 } & Sandhani Life insurance Co. Ltd. & 0.994 & 0.926 & 0.9600 \\
\cline { 2 - 5 } & Sunlife Insurance Co. Ltd. & 0.941 & 0.926 & 0.9335 \\
\cline { 2 - 5 } & Mean & $\mathbf{1 . 0 1 8}$ & $\mathbf{0 . 9 8 1}$ & $\mathbf{0 . 9 9 9 5}$ \\
\hline
\end{tabular}

As this study shows, table 6 reveals the changes in relative competence for each individual insurance operator. The results indicate significant variation across companies and time. It is very good to see that all the Takaful companies have been found to be consistently efficient, except Delta life Insurance Company through the year 2009 to 2011. During the entire period of study, the results indicate that, on average, the only Takaful operator under study, i.e. Padma Islami Life Insurance Limited experienced the highest efficiency change with16.8 percent, Pragoti Life Insurance Company that experienced efficiency decline by $(-52.0 \%)$. Finally, in case of Takaful operators the result shows that improvements have seen in positive improvement relative efficiency with $5.1 \%$ and deterioration with $2.5 \%$ in terms of life insurance companies throughout the study period 20092011.Maximum efficiency showed 7.55 percent by Rupali Life Insurance Limited. 
Asian Business Review, Volume 3, Number 2/2013 (Issue 5)

ISSN 2304-2613 (Print); ISSN 2305-8730 (Online)

Table 6: Changes in Operators Relative Efficiency, 2009-2011

\begin{tabular}{|c|l|c|c|c|}
\hline Types & Name of the Insurance Company & $\begin{array}{c}\mathbf{2 0 0 9} \\
\mathbf{2 0 1 0}\end{array}$ & $\begin{array}{c}\mathbf{2 0 1 0 -} \\
\mathbf{2 0 1 1}\end{array}$ & Mean \\
\hline \multirow{4}{*}{$\begin{array}{c}\text { Takaful } \\
\text { Life }\end{array}$} & Fareast Islami Life Insurance Co. & 1.000 & 1.000 & 1.000 \\
\cline { 2 - 5 } & Padma Islami life insurance Ltd. & 1.013 & 1.323 & 1.168 \\
\cline { 2 - 5 } & Prime Islami life Insurance Ltd. & 1.000 & 1.000 & 1.000 \\
\cline { 2 - 5 } & Mean & $\mathbf{1 . 0 0 4}$ & $\mathbf{1 . 0 9 8}$ & $\mathbf{1 . 0 5 1}$ \\
\hline \multirow{5}{*}{$\begin{array}{l}\text { Life } \\
\text { Insurance }\end{array}$} & National Life Insurance Co. Ltd. & 1.000 & 1.000 & 1.000 \\
\cline { 2 - 5 } & Delta Life Insurance Bangladesh Ltd. & 1.000 & 1.000 & 1.000 \\
\cline { 2 - 5 } & Baira Life Insurance Ltd. & 0.998 & 0.968 & 0.983 \\
\cline { 2 - 5 } & Meghna Life Insurance Co. Ltd. & 0.979 & 0.983 & 0.981 \\
\cline { 2 - 5 } & Popular Life Insurance Co. Ltd. & 0.861 & 0.903 & 0.882 \\
\cline { 2 - 5 } & Pragoti Life Insurance Co. Ltd. & 0.768 & 1.328 & 1.048 \\
\cline { 2 - 5 } & Progressive Life Insurance Co. Ltd. & 1.000 & 1.000 & 1.000 \\
\cline { 2 - 6 } & Supali Life Insurance Co. Ltd. & 1.209 & 0.942 & 1.0755 \\
\cline { 2 - 6 } & Sandhani Life insurance Co. Ltd. & 0.880 & 0.879 & 0.8795 \\
\cline { 2 - 6 } & Sunlife Insurance Co. Ltd. & 0.980 & 0.952 & 0.966 \\
\cline { 2 - 5 } & Mean & $\mathbf{0 . 9 6 1}$ & $\mathbf{0 . 9 8 9}$ & $\mathbf{0 . 9 7 5}$ \\
\hline
\end{tabular}

In order to test a change in scale efficiency, the efficiency change is further decomposed into two subcomponents, namely pure efficiency change $(\mathrm{PECH})$ and scale efficiency change $(\mathrm{SECH})$ in which the results are reported in Table 7. The results indicate that the pure efficiency and scale efficiency appear to be a uniformly important source of growth to efficiency change. Two Takaful life insurance companies recorded no changes in annual growth for both the scale and pure efficiencies, except Padma Life Insurance Limited but it has made sound change compare to standard. Sunlife Life Insurance, Rupali Life Insurance, Meghna Life Insurance and popular life Insurance pure efficiency change was same to standard but differ in scale efficiency change during the period 2009 to 2011. Relative to other conventional insurance firms, Sandhani Life Insurance Company have attained the highest deterioration of scale efficiency at (-12.1) percent in scale efficiencies during the 2010-2011 study period and Popular life insurance Limited have opined the lowest growth of scale efficiency at (-13.9) percent during the study period through 2009-2010.And in case of Takaful life insurances, Padma Islami Life Insurance deteriorate by 3.3 percent. Baira Life Insurance change positively by 4.3 percent in case of conventional life insurances and in Takaful life insurance $5.9 \%$ by Padma Life Insurance Limited during the study period 2009 to 2011. In terms of average Takaful industries showed more efficiency in scale changes.

Table 7: Changes in Efficiency Components by Firms between Time Period $t$ and $t+1,2009-2011$

\begin{tabular}{|c|c|c|c|c|c|}
\hline \multirow[t]{2}{*}{ Types } & \multirow[t]{2}{*}{ Name of the Insurance Company } & \multicolumn{2}{|c|}{$\begin{array}{l}2009- \\
2010\end{array}$} & \multicolumn{2}{|c|}{$\begin{array}{l}2010- \\
2011\end{array}$} \\
\hline & & $\mathrm{PECH}$ & SECH & $\mathrm{PECH}$ & SECH \\
\hline \multirow{4}{*}{$\begin{array}{l}\text { Takaful } \\
\text { Life }\end{array}$} & Fareast Islami Life Insurance Co. & 1.000 & 1.000 & 1.000 & 1.000 \\
\hline & Padma Islami life insurance Ltd. & 1.048 & 0.967 & 1.249 & 1.059 \\
\hline & Prime Islami life Insurance Ltd. & 1.000 & 1.000 & 1.000 & 1.000 \\
\hline & \begin{tabular}{|c|} 
Mean \\
\end{tabular} & 1.016 & 0.989 & 1.083 & 1.020 \\
\hline \multirow{4}{*}{$\begin{array}{c}\text { Life } \\
\text { Insurance }\end{array}$} & National Life Insurance Co. Ltd. & 1.000 & 1.000 & 1.000 & 1.000 \\
\hline & Delta Life Insurance Bangladesh Ltd. & 1.000 & 1.000 & 1.000 & 1.000 \\
\hline & Baira Life Insurance Ltd. & 0.296 & 3.375 & 0.927 & 1.043 \\
\hline & Meghna Life Insurance Co. Ltd. & 1.000 & 0.979 & 1.000 & 0.983 \\
\hline
\end{tabular}

Copyright (C) 2013, Asian Business Consortium | ABR

\begin{tabular}{|l|l|c|c|c|c|}
\hline \multirow{1}{*}{} & Popular Life Insurance Co. Ltd. & 1.000 & 0.861 & 1.000 & 0.903 \\
\cline { 2 - 6 } & Pragoti Life Insurance Co. Ltd. & .464 & 1.654 & 1.370 & 0.970 \\
\cline { 2 - 6 } & Progressive Life Insurance Co. Ltd. & 1.000 & 1.000 & 1.000 & 1.000 \\
\cline { 2 - 6 } & Rupali Life Insurance Co. Ltd. & 1.000 & 1.209 & 0.922 & 1.021 \\
\cline { 2 - 6 } & Sandhani Life insurance Co. Ltd. & 1.000 & 0.880 & 1.000 & 0.879 \\
\cline { 2 - 6 } & Sunlife Insurance Co. Ltd. & 1.000 & 0.980 & 1.000 & 0.952 \\
\cline { 2 - 3 } & $\mathbf{0 . 8 2 0}$ & $\mathbf{1 . 1 7 2}$ & $\mathbf{1 . 0 1 6}$ & $\mathbf{0 . 9 7 4}$ \\
\hline Motean & PECH & Pure Efficiency Change, and SECH = Scale Efficiency Change.
\end{tabular}

In terms of pure efficiency, Padma Islami insurance Limited have achieved the highest increase by 4.80 percent in 2009-2010 and 24.90 percent in 2010-2011. There are no notable growths by conventional life insurances but dramatic drop by Baira Life Insurance in 2009-2010 and Pragoti Life Insurance made sound improvement by 37 percent. During the entire period of study, this research have identified as the years of pure efficiency improvement, while deterioration are recorded to be the years of scale efficiency.

\subsection{Productivity Performance of the Industry}

Table 8 summarizes the performance of the Malmquist productivity index of the whole life insurance (both conventional life and Takaful life) industry in Bangladesh during the year 2009 and 2011. In terms of conformist life insurances, Progressive Life Insurance Limited occupied first rank having highest growth in both TFP and TECH by same 9.9 percent and no change in efficiency and Rupali Life Insurance Limited recorded maximum increase in efficiency change with 6.7 percent during the study period. Moreover, Pragoti Life Insurance Limited has occupied second rank with $4.10 \%$ improvement in both TFP and TECH but no change in efficiency. Furthermore, Sandhani Life Insurance Limited has experienced with 15.6 percent deterioration in TFP 12 percent and 4.1 percent in efficiency change and TECH respectively.

In case of Takaful life insurances industries, on average, Padma Islami Life Insurance Limited recorded the highest growth in TFP and efficiency change with 11.20 $\%$ and $15.80 \%$ respectively and negative technical changes with $(-4.00 \%)$. In contrast Fareast Islami Life Insurance Company has shown result the lowest growth in TFP and same as technical change with (-14.80) percent and interesting see that no change in efficiency. In addition, Prime Islami Life Insurance Limited has experienced $6.8 \%$ retreats growth in TFP because of same deterioration in technical changes.

On average, the TFP of the Takaful life insurances industry is just below the pure efficient level, mainly due to both efficiency and technical changes with 5.30 and (08.50) percents, respectively. Additionally, the efficiency change is largely contributed by $\mathrm{PECH}$ compare than scale efficiency. In comparison, the TFP of the rational insurance industries is below the scale efficient level, mainly due to both efficiency and pure efficiency changes negatively with 2.5 percents and 8.7 percents respectively. Additionally, the efficiency change is 
largely contributed by SECH rather than $\mathrm{PECH}$. This indicates that the size of the companies is not a factor in affecting efficiency changes. This study found that there were very substantial growths in efficiency components and pure efficiency change which suggest that TFP in the Takaful life insurances industry is better than conventional life insurances operators due to the innovation in technical components coupled with a considerable improvement in the efficiency aspect. In case of life Takaful life insurances industry of Bangladesh has faced more negative impact of technical changes than a positive efficiency, the overall TFP for these firms within the period of study is maintained at a value slightly lower than 1 (reflected by the mean 0.965 of TFP change). In contrary, in case of non-life Takaful Industry of Bangladesh has faced same direction impact of technical changes than a negative efficiency change; the overall TFP for these firms within the period of study is maintained at a value a little bit lower than by 0.02 percent.

Table 8: Summary of the Malmquist Productivity Index of Insurance Operators, 2009-2011

\begin{tabular}{|c|c|c|c|c|c|c|}
\hline \multicolumn{2}{|r|}{ Na } & EFFCH & \multicolumn{2}{|c|}{ TECHCH PECH } & SECH & \multirow{2}{*}{$\frac{\text { TFPCH }}{0.852}$} \\
\hline & Fareast Islami Life Insurance Ltd & 1.000 & 0.852 & 1.000 & 1.000 & \\
\hline & Padme & 1.158 & & 1.144 & 1.012 & \\
\hline & Prime Islami life & 000 & & 000 & 1.000 & \\
\hline & \begin{tabular}{|c|} 
Mean \\
\end{tabular} & 053 & 5 & 1.048 & 1.004 & 0.96 \\
\hline \multirow{11}{*}{ 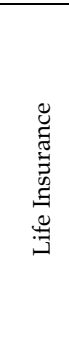 } & National Life I & .000 & 990 & 1.000 & 1.000 & 0.990 \\
\hline & Delta Life Insurance Ltd. & 1.000 & 972 & 1.000 & 1.000 & 0.972 \\
\hline & Baira Life Insurance Ltd. & 0.983 & 025 & 0.524 & 1.877 & \\
\hline & Meg & & & 1.000 & 0.981 & 1.012 \\
\hline & $\overline{\text { Popt }}$ & 010 & & 00 & 0.882 & 88 \\
\hline & Pragc & 000 & & 0.797 & 1.266 & 1.041 \\
\hline & Progres & 1.000 & 1.099 & 1.000 & 1.000 & 1.099 \\
\hline & Rupal & 1.067 & 0.944 & 0.960 & 1.111 & 1.008 \\
\hline & Sandhani Life in & 0.880 & 0.959 & 1.000 & 0.880 & 0.844 \\
\hline & Sunlife Insurance & 0.966 & 0.933 & 1.000 & 0.966 & 0.901 \\
\hline & $\begin{array}{r}\text { Mean } \\
\end{array}$ & 0.975 & 0.999 & 0.913 & 1.069 & 0.974 \\
\hline
\end{tabular}

Note: TFPCH $=$ Total Productivity Change; EFFCH = Efficiency Change; TECHCH = Technical Change; $\mathrm{PECH}=$ Pure Efficiency Change; and $\mathrm{SECH}=$ Scale Efficiency Change.

It may conclude, by measuring the efficiency of life insurances operators in Bangladesh that Takaful life insurances performed better except pure efficiency change than traditional life insurance industries during the taken study period.

Figure 1(a) reveals the mean evolution over time of TFP and its components for the Takaful life insurances measured by the geometric mean of the Malmquist productivity index for each period. The figure displays that on average, TFP occupied the maximum growth in efficiency change during the 2009-2010 and decrease of TFP in the subsequently periods of 2010-2011 which was largely contributed by the improvement of efficiency change rather than technical changes.

Figure 1 (a): Changes in Mean TFP and its components for Takaful life insurances, 2009-2011.

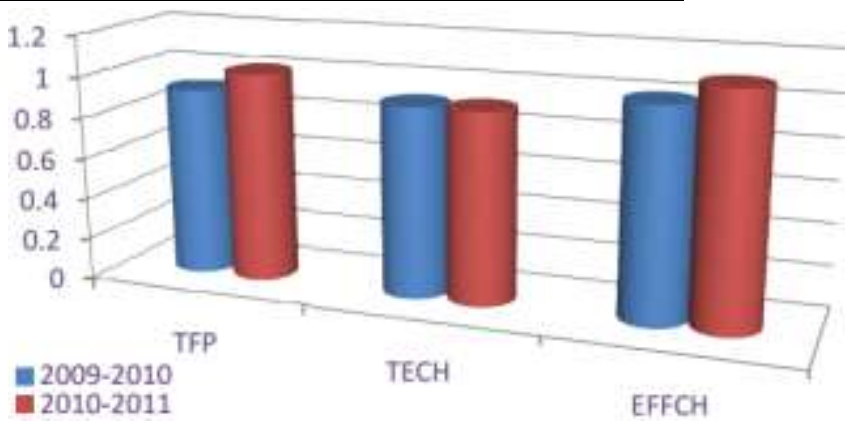

To evaluate the efficiency of Takaful life and conventional life insurances in this work try to use graph. By which may assess productivity easily. Figure 1 (b) presents the visual synopsis of changes in the mean efficiency and its components which are scale and pure efficiencies for the entire study periods. For the study period of 2009-2011, the mean efficiency changes improve within the study period which has made a significant impact on the overall of TFP change.

Figure 1 (b): Changes in Mean efficiency and its components for Takaful life insurance, 2009-2011.

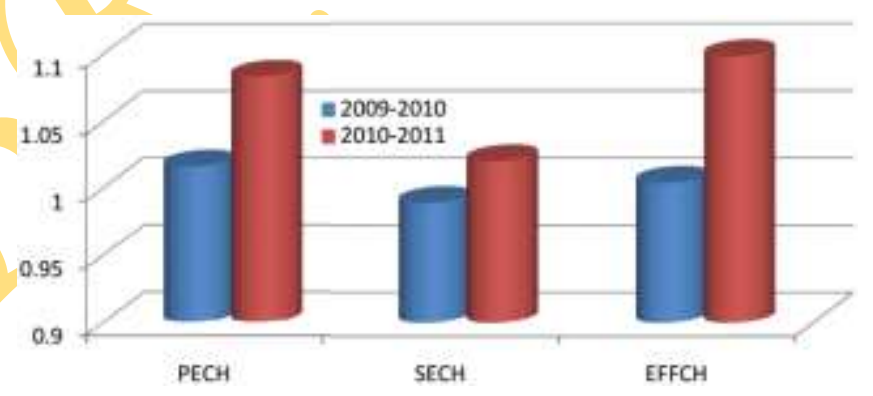

On the other hand, in case of PECH and EFFCH is experienced by a significant amount of improvement then 2009-2010.And there seen that there are positively change in all criteria of Takaful life insurances. According to the figure, it seems that the change in efficiency has superior by a positive changes in scale efficiency and pure efficiency.

Figure 2 (a): Changes in Mean TFP and its components for conventional life insurances, 2009-2011.

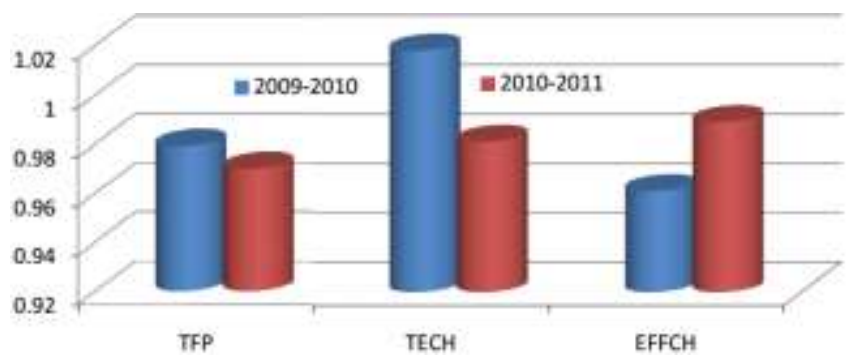

In figure 2 it attempts to emphasize measure the productivity of conventional life insurance in Bangladesh. It represents the visual summary of changes 
in the mean efficiency and its components which are scale and pure efficiencies for the entire study periods. For the study period in 2010-2011, the mean efficiency change increase then previous study year which has made a significant impact on the overall of TFP change. Here is seen that technical efficiency change dramatically in 2010-2011 which was in much better previous study year and TFP change as same direction but very few.

Figure 2 (b): changes in Mean efficiency and its

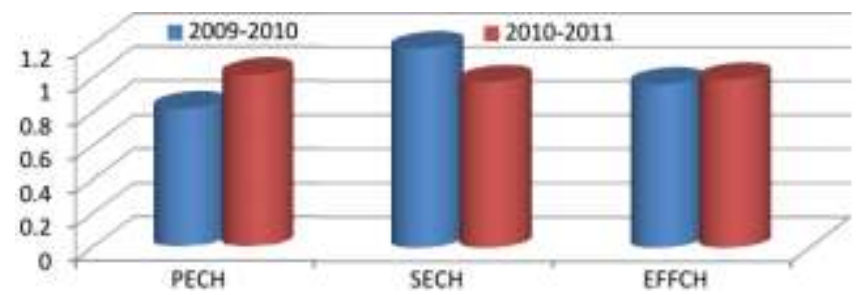

components for rational life insurances, 2009-2011.

On the other hand, in case of pure and scale efficiency, scale efficiency is experienced by a significant amount of improvement in 2009-2010 but the situation changed a little bit in case of scale efficiency. According to the figure, it seems that the change slightly higher by a change in pure efficiency rather than a change in scale efficiency.

Finally, Figure 2 presents the visual summary of changes in the mean efficiency and its components which are scale and pure efficiencies for the entire study periods. For the study period of 2009-2011, the mean efficiency change decline within the study period which has made a significant impact on the overall of TFP change. On the other hand, in case of pure and scale efficiency, scale efficiency is experienced by a significant amount of deterioration but the situation unchanged in case of scale efficiency. According to the figure, it seems that the change in efficiency has declined by a change in scale efficiency rather than a change in pure efficiency.

\section{Conclusion}

This report attempts to develop the work aspires is to test the competence for Takaful life and conventional life insurances industry of Bangladesh. Data Envelopment Analysis (DEA) is used to explore the contributions of technical and efficiency changes to the growth of productivity in the conventional life and Takaful life industries of Bangladesh by using descriptive statistics such as mean, median, standard deviation, minimum \& maximum and efficiency (Constant Returns to Scale \& Variable Returns to Scale) applying the generalized output-oriented Malmquist index for the years 20092011. ).In this evaluation seen Takaful life insurance played efficiency except in technical efficiency change by 8.4 percent less compare to conventional life insurance as per Malmquist index. This report reveals there are some inefficient life insurance companies in the conventional one. For these poor performances conventional industries show less productivity then Takaful life insurances operators. As there are dual financial system are practicing Takaful show efficient performance. This result indicates that Takaful life insurance industries have a great potential to further increase their TFP through improvements in both efficiency and technical component such as enhancing the use of information and communication technology in order to provide good services to customers. However, this study also found that there were diminutive significant growths in technical components and no improvement in efficiency change which suggest that TFP in the Islamic Insurance industry is due to the less innovation in technical components coupled with a insignificant improvement on the aspect of efficiency.

The focal finding of this study indicates that in the life insurances industry of Bangladesh, the smaller the size of the companies in Takaful life insurances, the higher the probability for the companies to be more efficient in utilizing their inputs to generate more outputs. Among them Padma Life Insurance Limited is making better performance in Takaful life insurances and Delta Life insurance tried to keep their consistency where Pragoti Life Insurance Limited is lees inconsistent other competitors. Baira Life insurance Limited falls greatly from their performance in 2010-2011 in VRS. Overall, Progati Life Insurance Limited has recorded the highest growth in TFP with 66.7 percent and efficiency change (just 1) and technical changes with 19.4 percent. Fareast Islami Life Insurance Company, on the other hand, recorded the lowest growth in TFP with (-12.9) percent, which is mainly due to technical regress (-12.9 percent. The findings of this study give significant benefits to the life insurances industry in assisting them to take strategies in terms of the operations and management in order to improve the efficiency of both industries in utilizing their inputs to generate more outputs, thus, improving their competitive edge and strengthening their positions in the industry further. In the DEA technique, efficiency is measured by the Malmquist index. The Malmquist efficiency measures have two components: the efficiency change and technical change index. . On average, the insurance firms are found to be experiencing a technical progress. In contrast there was a slight decline in efficiency change, the subcomponent of this efficiency change, namely pure efficiency, did show a slight improvement .Efficiency change is again combined by pure efficiency and scale efficiency. It is found that, on geometric mean, the TFP of the Takaful life insurance industry is mainly due to both efficiency and technical changes where the main source of the efficiency change is pure efficiency rather than scale efficiency. So this works shows despite having potentiality due to inefficient operator's life insurances companies can't gain success in this country. In these sense, Takaful life insurances is doing well. This works expect this effort will be helpful for researchers and practitioners to better comprehend the Bangladeshi life insurances industry. 


\section{REFERANCES}

[1] Abidin Z. \& Cabanda E.,(2011), efficiency of non-life insurance in indonesia, Journal of Economics, Business and Accountancy Ventura,14(3), 197 - 202.

[2] AFZA T. \& Jam-e-Kausar, (2010), Efficiency of the Insurance Industry in Pakistan: An Application of Non-parametric Approach, interdisciplinary journal of contemporary research in business, 2 (8), 84-98.

[3] Afza T. \& Jam-e-Kausar, (2010), Firm size and efficiency in the non-life insurers of Pakistan, Journal of Quality and Technology Mgt Forthcomming .

[4] Ali, M. M. K.,(2000), Provision of micro-insurance for microfinance clients. Microfinance Newsletter, 7, 2-5.

[5] Barros,C.P.; Barroso, N. and Borges, M.R., (2005). Evaluating the Efficiency and Productivity of Insurance Companies with a Malmquist Index: A Case Study for Portugal. Geneva Papers on Insurance, 30, 244-267.

[6] Barros, P., Obijiaku, E. L., (2007). Technical Efficiency of Nigerian Insurance Companies. Department of Economics, Institute for Economics and Business Administration (ISEG), Technical University of Lisbon. WP No. 18.

[7] Berger, A.N, Hunter, W.C., \& Timme, S.G., (1993). The efficiency of financial institutions: $A$ review and preview of research past, present and future. Journal of Banking and Finance, 17(2\&3), 221-250.

[8] Berger, A. N., Humphrey, D. B., (1997). Efficiency of Financial Institutions: International Survey and Directions for Future Research. European Journal of Operational Research 98 (2), 175-212.

[9] Coelli, T. J., (1996a). A Guide to Deap Version 2.1: A Data Envelopment Analysis (Computer) Program, Working Paper No. 8/96, Department of Econometrics, University of New England.

[10] Cummins, J. D., Turchetti, G., Weiss, M. A., (1996). Productivity and Technical Efficiency Italian Insurance Industry. Working Paper, Wharton Financial Institutions Center, University of Pennsylvania, PA.

[11] Cummins, J. D., Zi, H., (1998). Comparison of Frontier Efficiency Methods: An Application to the U.S. Life Insurance Industry. Journal of Productivity Analysis 10 (2), 131-152.

[12] Cummins, J. D., Weiss, M. A., Zi, H., (1999). Organizational Form and Efficiency: The Coexistence of Stock and Mutual Property-Liability Insurers. Management Science 45 (9), 1254-1269.

[13] Cummins, J. D. and Rubio-Misas, M. (2001). Deregulation, consolidation, and efficiency: evidence from the spanish industry, Working Paper Series, The Wharton School, University of Pennsylvania.

[14] Cummins, J.D. and Weiss, M.A., (2002). "Analysing Firm Performance in the Insurance Industry, using Frontier efficiency Methods". In Dionne, G. (ed), Handbook of Insurance Economics. Kluwer, Boston, 767-829

[15] Diacon, S. R., (2001). The Efficiency of UK General Insurance Companies. Working Paper, Centre for Risk \& Insurance Studies, University of Nottingham.

[16] Fare, R., Shawna, G., Bjorn, L., \& Ross, P.(1989). Productivity development in Swedish hospitals: $A$ Malmquist output index approach. Mimeo.
[17] Fare, R., Shawna, G., Mary, N., \& Zhongyang, Z.,(1994), Productivity growth, technical progress and efficiency change in industrialized countries. American Economic Review, 84, 66-83.

[18] Forsund, F. 1991. The Malmquist productivity index. Paper presented at the $2^{\text {nd }}$ European Workshop on Efficiency and Productivity Measurement. Berlgium: Centre of Operations Research \& Econometrics, University Catholique de Louvain, Lauvain-la-Neuve.

[19] Fukuyama, H., (1997). Investigating Productive Efficiency and Productivity Changes of Japanese Life Insurance Companies. Pacific-Basin Finance Journal 5 (4), 481- 509.

[20] Jesmin et al (2013) "Measures of Efficiency in the Takaful Industry of Bangladesh- A Non Parametric Approach." EJBM-Special Issue: Islamic Management and Business, 5 (11), 163-173.

[21] Kessner, K., Polborn, M., (1999). Eine Effizienzanalyse der deutschen Lebensversicherer-die Best Practice Methode. Zeitschrift für die gesamte Versicherungswissenschaft 88, 469-488.

[22] Leong, W.H., Dollery, B., \& Coelli, T.,(2003), Measuring technical efficiency of banks in Singapore for the period 1993-1999: An application and extension of the Bauer et al.,1997 technique. ASEAN Economic Bulletin, 20(3), 195-210.

[23] Mahlberg, B., Url, T., (2003). Effects of the Single Market on the Austrian Insurance Industry. Empirical Economics 28, 813-838.

[24] Mahlberg, B and Url, T., (2010). Single Market effects on productivity in the German insurance industry, Journal of Banking \& Finance Vol. 34, No. 7, 1540-1548.

[25] Mansor, S. A., Radam, A., (2000). Productivity and Efficiency Performance of the Malaysian Life Insurance Industry. Jurnal Ekonomi Malaysia 34, 93-105.

[26] Meador, J. W., Ryan, Jr., H. E., Schellhorn, C. D., (2000). Product Focus Versus Diversification: Estimates of X-Efficiency for the US Life Insurance Industry. Working Paper, Wharton Financial Institutions Center University of Pennsylvania.

[27] Neal, P., (2004),. X-efficiency and productivity change in Australian banking. Australian Economic Papers, 13(2), 174-191.

[28] Noulas, A. G., Hatzigayios, T., Lazaridis, J., Lyroudi, K., (2001), Non-Parametric Production Frontier Approach to the Study of Efficiency of Non-Life Insurance Companies in Greece. Journal of Financial Management and Analysis 14 (1), 19-26.

[29] Rees, R., \& Kessner, E., (2000), Regulation and efficiency in European insurance markets. Economic Policy, 29, Centre for Economic Policy Research, London.

[30] Saad M., N., Abd. Majid, M.S., Mohd. Yusof, R., Duasa, J., \& Abdul Rahman, A.R., (2007). Measuring efficiency of insurance and takaful companies in Malaysia using data envelopment analysis (DEA). Review of Islamic Economics, 11(1), 5-26.

[31] Saad M., (2012), An Analysis on the efficiency of TAKAFUL and insurances companies in MALAYSIA: A Non-Parametricc Approach, Review of Interdisciplinary Business Research, 1 (1), 33-56. 
[32] Sabbir, P. (2002). Takaful and poverty alleviation, www.icmif.org/takaful

[33] Saeidy \& Kazentipour, (2011), Compare the Performance Public and Private Insurance Companies in Using Data Envelopment Analysis, World Applied Sciences Journal, 13(3), 988-992.

[34] Tone, K., Sahoo, B. K., (2005). Evaluating Cost Efficiency and Returns to Scale in the Life Insurance Corporation of India Using Data Envelopment Analysis. Socio-Economic Planning Sciences 39 (4), 261-285.
[35] Weiss, M. A., (1991a). Efficiency in the PropertyLiability Insurance Industry. Journal of Risk and Insurance 58 (3), 452-479.

[36] Worthington, A. C., Hurley, E. V., (2002). Cost Efficiency in Australian General Insurers:A Non-Parametric Approach. The British Accounting Review 34 (2), 89-108.

[37] Wu, D., Yang, Z., Vela, S., Liang, L.,(2007). Simultaneous Analysis of Production and Investment Performance of Canadian Life and Health Insurance Companies Using Data Envelopment Analysis. Computers \& Operations Research 34 (1), 180-198.

$-0$ 